https://doi.org/10.48009/2_iis_2005_224-230

\title{
MOTIVATING FACTORS ON INFORMATION TECHNOLOGY EMPLOYEES IN BAHRAIN HOTEL INDUSTRY
}

\author{
Dr. Adel Ismail Al-Alawi, University of Bahrain, alalawi@itc.uob.bh
}

\begin{abstract}
Historically, managers in any organization have always used motivation as a technique to perform tasks and duties. Motivation of staff is a major issue for all organizations. Humans are motivated by many factors such as psychological needs, physiological drives, survival, urges, emotions, hurts, impulses, fears, threats, reward, possessions, wishes, intentions, values, freedom, intrinsic satisfaction, self-satisfaction, pleasure, dislikes, established habits, goals, ambitions, and above all, money. This study discusses the motivational factors that affect employees in different departments and focuses on motivating information technology (IT) employees in the hotel industry. A survey was distributed among different levels of managers in different departments. Interviews were also conducted with IT managers and training managers. It examines and explores the motivational factors that will affect productivity and employee performance. Moreover, this study covers data analysis and discusses the relationships between demographic data, socioeconomic data, organizational data, and motivational factors. The research concludes that the motivational factors ( environmental factors, management factors, opportunities and training in the workplace, and job satisfaction) are essential to motivate the IT hotel employees. Training on a regular basis is the most motivational method to IT employees.
\end{abstract}

Keywords: Motivation, MIS, IT, Hotel, Employee, Factor, Bahrain.

\section{INTRODUCTION}

Historically, managers in any organization have always used motivation as a technique to perform tasks and duties. Motivation of staff is a major issue for all organizations. Humans are motivated by many factors such as psychological needs, physiological drives, survival, urges, emotions, hurts, impulses, fears, threats, reward, possessions, wishes, intentions, values, freedom, intrinsic satisfaction, self-satisfaction, pleasure, dislikes, established habits, goals, ambitions, and above all, money [3, 5, 8, 17].

The hotels in Bahrain play a major role in attracting tourists to the island. In Bahrain there are more than 81 star hotels, which include 8 five star hotels, 8 four star hotels, 20 three star hotels, 32 two star hotels, 13 one star hotels [see 14, 20, 21]. These hotels employ more than 6000 people who consist of Bahraini as well as expatriate employees. To maintain Bahrain's position as a major tourist attraction in Gulf Cooperation Countries (GCC) -Bahrain, Kuwait, Saudi Arabia, Qatar, United Arab Emirates and Oman - it is important for the hotels to keep a high quality of service. This can be done only if the employees are motivated enough to perform their job effectively and efficiently.

In the literature, there are ranges of sources, which address the factors for motivation in the hotel industry. To date there is lack of research in this field in Bahrain. Bahrain is expanding -literallyto accommodate its nascent tourism industry and create space for an expected influx of visitors. 
However, it is essential that Bahrain develops a long term tourism blueprint for any further progress in tourism ventures. Bahrain has everything (maybe one word everything) it needs to develop as a tourism destination - friendly people, safety and a current major infrastructure development project. In term of technology and cultural heritage it offers the best of both worlds, but if it is to succeed then all the pieces need to be in place.

This study discusses the motivational factors that affect employees in different departments, and focuses on motivating information technology employees in the hotel industry. A survey was distributed among different levels of managers in different departments. Interviews were also conducted with information technology managers and training managers. It examines and explores the motivational factors that will affect productivity and employee performance. Moreover, this study covers data analysis and discusses the relationships between demographic data, socioeconomic data, organizational data, and motivational factors.

\section{METHODOLOGY}

The survey methodology used for collecting data involved visits, interviews, and the distribution of questionnaires. An initial version was drafted and tested on a specimen of the target population. To determine the state of art of motivation in the hotel industry in Bahrain, the author visited the concerned hotels, had discussions with the staff, distributed the questionnaire and held interviews with the managers of these hotels. These interviews were deliberately unstructured and wide ranging since the overall aim was to get a broad understanding of the state of motivation in this sector. To obtain a more complete picture than could be obtained from interviews, it was felt that the questionnaire method would generate rich data while at the same time minimizing the time and effort required of the respondents.

The questionnaire was designed after a survey of motivation literature $[1,3,4,5,6,11,13,14$, $16,17]$. The questionnaire had two parts. Part one was directed to the identification of the respondent in order to assist in the analysis and to provide access to individuals for any necessary clarification. Part two of the questionnaire focused on the study of sub-problems. The questionnaire was distributed to all department managers as well as IT managers to determine the conditions of what different factors that motivate IT employees while performing their duties. There were a total of 95 participants for the questionnaire, 73 managers of all departments and 22 Information Technology managers and supervisors.

\section{REVIEW OF LITERATURE}

Employees are considered an important input for the production of goods and delivery of services. Understanding what motivates employees and how they were previously motivated plays an important role in gaining competitive advantage.

"Motivation is the set of forces that causes people to engage in one behavior rather than some alternative behavior" [15]. Also many authors have defined the concept of motivation "as the psychological process that gives behavior purpose and direction" [10]; "an internal drive to satisfy an unsatisfied need" [7]; and "the will to achieve" [2]. So, the motivation is the inner force that drives individuals to accomplish personal and organizational goals. 
Understanding the factors that affect employee motivation is a complex process. It involves the unique feelings, thoughts, and past experiences of each individual as we share a variety of relationships within and outside the organization.

Need theories represent the starting point for most contemporary thought on motivation, or what some others call "content theories" [8]. The best-known need theories are hierarchy of needs and the Existence Relatedness and Growth Theory (ERG Theory). The hierarchy of needs was developed by psychologist Abraham Maslow in the 1940s. Maslow argued that human beings have desires to satisfy, which are represented by a given set of needs. Also, Maslow believed that these needs are arranged in a hierarchy of importance, with the most basic needs at the root of the hierarchy [12] and the E, R, and G stand for the three basic need categories: Existence, Relatedness, and Growth. Existence needs means those necessary for basic human survival, relatedness needs involving the need to relate to others, and finally growth needs are analogous to Maslow for self-esteem and self-actualization [15].

There was little research related to the question under study. In general, the studies found that providing a suitable working environment, recognition and rewards, teamwork, simplicity environment, and hiring the right worker was a significant step for any company [18].

Kawme and Lincoln's [9] study concludes that male workers were more attracted to high wages than females. Also, as age increased, supervision over other workers declined and "Job Security" became a serious demand. They found that employees, who were working for a long time, were less interested in their jobs but were highly motivated by higher wages. And employees who had lower connections with guests were motivated by "appreciation of the work done" more than employees dealing with guests more often.

Motivation becomes a significant factor in the hospitality environment. The need for clearly defined methods toward motivating employees is also critical; therefore, this section focuses on discussing the most important motivational theories and reviews some of the motivational studies, which is considered to be the first step in understanding the idea of motivation in the hotel industry.

\section{DATA ANALYSIS AND DISCUSSION}

The analysis was carried out using the Statistical Package for Social Sciences (SPSS), which was used to generate particular data. Among its many features are modules for statistical data analysis, including descriptive statistics such as plot, frequencies, charts, and categorical data analysis. SPSS was used in this project because it is well suited to analyze survey research. In order to assure statistically reliable results, a questionnaire was distributed to managers to gain knowledge on their thoughts and attitudes towards motivation and to staff in different departments, especially the Information Technology Department- to smooth the way headed for better quality service and higher performance.

Table 1 shows the limitation of the research. The hotel classification is represented in three categories: five star hotels, four star hotels, and resorts only. The greater part of the sample size was five star hotels (56.8\%), four star hotels (28.4\%), and resorts (14.7\%). 
Table 1. Hotel Classifications

\begin{tabular}{lccccc}
\multicolumn{2}{l}{ Hotel Category } & Frequency & Percent & Valid Percent & Cumulative Percent \\
\hline Valid & 5 star & 54 & 56.8 & 56.8 & 56.8 \\
& 4 star & 27 & 28.4 & 28.4 & 85.3 \\
& Resort & 14 & 14.7 & 14.7 & 100.0 \\
& Total & 95 & 100.0 & 100.0 &
\end{tabular}

Table 2 shows about (21.1\%) of the respondents were Bahraini nationals, while (44.2\%) represent Asian respondents from all departments. The majority of the sample by department were administrative staff, while $(23.2 \%)$ of the respondents were IT Department staff members.

Table 2. Nationalities

\begin{tabular}{llcccc} 
Nationality & Frequency & Percent & Valid Percent & Cumulative Percent \\
\hline Valid & Bahraini & 20 & 21.1 & 21.1 & 21.1 \\
& Arab & 11 & 11.6 & 11.6 & 32.6 \\
& Asian & 42 & 44.2 & 44.2 & 76.8 \\
& European & 16 & 16.8 & 16.8 & 93.7 \\
& American & 1 & 1.1 & 1.1 & 94.7 \\
& Others & 5 & 5.3 & 5.3 & 100.0 \\
& Total & 95 & 100.0 & 100.0 &
\end{tabular}

By analyzing the data gathered from question three in the questionnaire, the following results were obtained: The Letter of Appreciation has the highest response of (95.8\%). The second motivational method used is Employee of the Month/Year with a percentage of (89.5), while (71.6\%) have responded to the Salary Increase and Bonus. The least used method is Pay Traveling/ Holiday because it would increase the hotels' expenses (see Table 3).

Table 3. Motivational Methods

\begin{tabular}{|c|c|c|c|c|c|}
\hline Motivational Methods & Yes $(\%)$ & No $(\%)$ & Motivational Methods & Yes $(\%)$ & No $(\%)$ \\
\hline $\begin{array}{l}\text { 1.Letter of } \\
\text { Appreciation }\end{array}$ & 95.80 & 4.20 & 7.Birthday Parties & 60 & 40 \\
\hline $\begin{array}{l}\text { 2.Employee of the } \\
\text { Month/Year }\end{array}$ & 89.50 & 10.50 & 8.Cash Rewards & 47.40 & 52.60 \\
\hline 3.Salary Increase & 71.60 & 28.40 & $\begin{array}{l}\text { 9. Recognition through } \\
\text { Newspapers }\end{array}$ & 32.60 & 67.40 \\
\hline 4.Bonus & 71.60 & 28.40 & 10.Gift Vouchers & 25.30 & 74.70 \\
\hline 5.Promotion & 69.50 & 30.50 & 11.Family Day Out & 16.80 & 83.20 \\
\hline 6.Training & 68.40 & 31.60 & $\begin{array}{l}\text { 12.Paid } \\
\text { Traveling/Holiday }\end{array}$ & 14.70 & 85.30 \\
\hline
\end{tabular}

Table 4 shows employee-motivating factors in the work environment. Teamwork, great working conditions, competitive environment, and expressing ideas is essential to motivate employees. 
Table 4. Percentages of Responses Toward the Work Environment Factors

$\begin{array}{lccccc}\begin{array}{l}\text { Work Environment } \\ \text { Factors }\end{array} & \begin{array}{c}\text { Strongly } \\ \text { Agree }\end{array} & \text { Agree } & \text { Neutral } & \text { Disagree } & \begin{array}{c}\text { Strongly } \\ \text { Disagree }\end{array} \\ \begin{array}{l}\text { 1.An atmosphere of } \\ \text { teamwork is important. }\end{array} & 78.9 \% & 21.1 \% & 0 \% & 0 \% & 0 \% \\ \quad \begin{array}{l}\text { 2.Good working conditions } \\ \text { are essential to motivate. }\end{array} & 77.9 \% & 21.1 \% & 1.1 \% & 0 \% & 0 \% \\ \quad \begin{array}{l}\text { 3.Competitive environment is } \\ \text { important. }\end{array} & 48.4 \% & 44.2 \% & 7.4 \% & 0 \% & 0 \% \\ \quad \begin{array}{l}\text { 4.Power of position is } \\ \text { important in the workplace. }\end{array} & 9.5 \% & 29.5 \% & 29.5 \% & 28.4 \% & 3.2 \% \\ \quad \begin{array}{l}\text { 5.Expressing of ideas and } \\ \text { concerns freely is an effective } \\ \text { factor. }\end{array} & 46.3 \% & 46.3 \% & 7.4 \% & 0 \% & 0 \%\end{array}$

Table 5 shows the motivating factors related to management. About (78.9\%) of the respondents strongly agreed on recognition from management, so recognition is important to motivate employees in order to increase the quality of service.

Table 5. Percentages of Responses Toward Management Factors

\begin{tabular}{|c|c|c|c|c|c|}
\hline Management Factors & $\begin{array}{c}\text { Strongly } \\
\text { Agree }\end{array}$ & Agree & Neutral & Disagree & $\begin{array}{l}\text { Strongly } \\
\text { Disagree }\end{array}$ \\
\hline $\begin{array}{l}\text { 1.Equal and non-discriminatory } \\
\text { salary structure is important. }\end{array}$ & $61.1 \%$ & $34.7 \%$ & $4.2 \%$ & $0 \%$ & $0 \%$ \\
\hline $\begin{array}{l}\text { 2.Training all employees equally } \\
\text { is essential to motivation. }\end{array}$ & $56.8 \%$ & $33.7 \%$ & $8.4 \%$ & $1.1 \%$ & $0 \%$ \\
\hline $\begin{array}{l}\text { 3.Appreciation and recognition } \\
\text { from the management are needed. }\end{array}$ & $78.9 \%$ & $18.9 \%$ & $2.1 \%$ & $0 \%$ & $0 \%$ \\
\hline 4.Sympathetic personal help & $48.4 \%$ & $36.8 \%$ & $13.7 \%$ & $1.1 \%$ & $0 \%$ \\
\hline $\begin{array}{l}\text { 5.Job rotation is an effective } \\
\text { technique to motivate emplovees }\end{array}$ & $29.5 \%$ & $53.7 \%$ & $11.6 \%$ & $5.3 \%$ & $0 \%$ \\
\hline
\end{tabular}

Table 6 clearly defines the importance of job security, with (47.4\%) agreeing that this factor was important. Some of the respondents thought that they were underpaid as compared to other organizations. (56.9\%) agreed on this conclusion, others (13.7\%) disagreed with this. Still, recognition is very important toward job satisfaction; (97.9\%) agreed with this factor.

Table 6. Percentages of Responses toward Job Satisfaction Factors.

\section{Job Satisfaction Factors}

1.Job security is needed.

2.Employees in hotel industry are underpaid.

3.Job title is important.

4.Interesting work is an

advantage factor toward

motivation.

$\begin{array}{ccccc}\begin{array}{c}\text { Strongly } \\ \text { Agree }\end{array} & \text { Agree } & \text { Neutral } & \text { Disagree } & \begin{array}{c}\text { Strongly } \\ \text { Disagree }\end{array} \\ 41.1 \% & 47.4 \% & 11.6 \% & 0 \% & 0 \% \\ 11.6 \% & 45.3 \% & 29.5 \% & 13.7 \% & 0 \% \\ & & & & \\ 14.7 \% & 48.4 \% & 31.6 \% & 4.2 \% & 1.1 \% \\ 60 \% & 35.8 \% & 1.1 \% & 3.2 \% & 0 \%\end{array}$



5.Recognition leads to job satisfaction.
$61.1 \%$
$36.8 \%$
$2.1 \%$
$0 \%$
$0 \%$

Furthermore, respondents argued that in-house training was not a better option than outsourcing the training of employees. They believed employees could gain more experience and learn new skills in a more efficient manner from outside agencies that were specialized in the field. IT workers insisted on regular training, which would give them the capabilities and expertise to run the hotel with the most updated programs, which in turn should contribute to the smooth flow of work on a daily basis.

About 11 IT respondents agreed that equal and non-discriminatory salary structure was important; 13 strongly agreed that training all employees equally was essential to motivation; 16 of the respondents indicated that appreciation and recognition from the management was needed to motivate employees. Sympathetic personal help was viewed as an important factor from the IT employees' perspective. Another important factor to IT employees was job rotation, which aimed at reducing repetitive jobs for each employee.

Finally, the results also showed that Operational and Middle Managers were not satisfied with their income but believed that the job title and an interesting work environment were important.

\section{RECOMMENDATIONS}

As Bahrain's tourism industry is currently experiencing a boom, hotels need to motivate their work force in order to reflect the kindness the Bahraini society has to offer. One can recommend conferences to be held for the IT department workers from all hotels, which will enable them to share their future vision, suggest ways to solve technical problems and suggest ways to implement new programs to cope with the tourism boom. We also recommend training on a regular basis, including accepting contributions from staff members in choosing and designing the training courses, which in turn should assist employees to work more efficiently. We faced a few problems with some hotels who were not very understanding when it came to research. The hotels should be more flexible and cooperative with any future researchers because it will provide them with valuable results and may also bring situations which they were not aware of to their attention. Hotels should develop plans to motivate employees by satisfying their needs. Suggestions include social days, social committees, cash rewards and building a committee of staff members to contribute in the management decisions making process.

\section{CONCLUSION}

There is no structured motivational activity; the reason for this being that the majority of staff in the hotel industry is composed of expatriates and their coming to Bahrain was an act of motivation itself. Therefore this research studied the most common factors investigated by previous researchers. The work environment should be suitable to employees in order to compete, interact with other employees in the workplace, express ideas freely, and satisfy their needs. The research concluded that the motivational factors (environmental factors, management factors, opportunities and training in the workplace, and job satisfaction) are essential to 
motivate hotel employees. Training on a regular basis is the most important motivational tool for employees of the IT Department.

\section{REFERENCES}

1. Al-Alawi, A.I. (1991). Guidelines for Successful Development of Computerized Management Information Systems in Non-Profit Organizations, Unpublished Theses, School of Computer Studies, University of Leeds.

2. Bedeian, T. (1993). Motivation and Leadership in Workplace. (3 ${ }^{\text {rd }}$ ed.). London: McGrawHill.

3. Chesser, J.W. (1993). Hospitality Faculty: a Motivational Challenge. Cornell Hotel and Restaurant Administration Quarterly, 4(4), 69-77.

4. d'Andrade, R.G. (1992). Schemas and motivation. Cambridge: Cambridge UP, 23-44.

5. Feiertay, H. (1999). Environment: The Foundation of Motivation, Hotel and Motel Management, pp 48-49.

6. Geen, R.G. (1995). Human Motivation: A Social Psychological Approach. CA: Brooks/Cole.

7. Higgins, R. (1994). Work Motivational in Organizational Behavior. NY: Van Nostrand Reinhold.

8. Jay, W. (1989). Motivation in Organization. ( $2^{\text {nd }}$ ed.). NY: Wiley.

9. Kawme, R.C. and Lincoln, H.M. (1992). Motivational Preferences of Caribbean Hotel Worker. International Journal of Contemporary Hospitality Management, 4(3), 25-29.

10. Kreitner, W. (1995). Motivation and Leadership at Work. $\left(6^{\text {th }}\right.$ ed.). London: McGraw-Hill.

11. Markus, H.R. and Kitayamm, S. (1991). Culture and the Self: Implication for Cognition, Emotions, and Motivation. Psychological Review, 98, 224-253.

12. Maslow, A.H. (1970). Motivation and Personality. (2nd ed.). NY: Harper and Row.

13. Miller, J. (1997). Culture Conceptions of Duty: Implication for Motivation and Morality. NY: Routledge, 178-192.

14. Mook, D.G. (1987). Motivation: The Organization of Action. NY: Norton.

15. Moorhead, G. and Griffin, W. (1999). Managing People and Organizations. (6 ${ }^{\text {th }}$ ed.). NY: Houghton Mifflin.

16. Nusair, N. (1985). Human Nature and Motivation in Islam. The Islamic Quarterly, 24(3), 148-164.

17. Simons, T. (1995). Motivating Hotel Employees. Cornell Hotel and Restaurant Administration Quarterly, 36(1), 20-25.

18. Smith, G. (2002). How to Attract Keep Motivate Your Service Technicians [Online]. Available from:

http://www.americansweeper.com/news/NPE2002/GregSmithChartcourse.html [Accessed 28 June 2004].

19. Statistical Abstract (2003). Central Information Organization, Kingdom of Bahrain, [Online]. Available from: http:// www.Bahrain.gov.bh [Accessed 20 August 2004].

20. http:// www.bahraintourism.com [Accessed 20 August 2004].

21. http://www.discoverbahrain.com [Accessed 20 August 2004].

Acknowledgements. I would like to thank University of Bahrain's Scientific Research Council for funding this research. I would also like to thank Dr. Daniel Anderson, Mariam Al-Raees, Latifa Al-Shamlan, Fatima Al-Sabagh and Mohamed Fathi. 